\title{
ONLINE CLINICAL LEGAL EDUCATION: CHALLENGING THE
}

\section{TRADITIONAL MODEL}

\section{Les McCrimmon*, Ros Vickers** and Ken Parish***, \\ Charles Darwin University, Australia}

It has been suggested that the "Digital Age provides an opportunity to revitalize and modernize legal education and to make it more individualized, relevant, human, and accessible". ${ }^{1}$ Delivery of law degree programs fully online is one way the internet has begun to change, if not (yet) revolutionise, legal education in the twenty-first century. In Australia, law students have been able to obtain their law degree online for a number of years. Online clinical legal education, however, is still in its infancy.

In this article, the authors argue that the greater use of technology in legal education is inevitable, and law schools offering degrees fully online will continue to increase, at least in Australia. The rewards and risks of online legal education are considered from the perspective of a law school in which over $80 \%$ of its 855 students study law fully online. The development and implementation of clinical opportunities for students studying online also is discussed.

\section{INTRODUCTION}

In 2000, three respected American clinicians were invited by the Clinical Law Review to consider the issues they regarded as important to the future of clinical legal education.

\footnotetext{
*Les McCrimmon is Professor of Law at Charles Darwin University and a Fellow of the Australian Academy of Law. He was formerly a full-time Commissioner with the Australian Law Reform Commission, and the Director of Clinical Programs at the University of Sydney. He also served on the International Steering Committee of the Global Alliance for Justice Education for six years.

** Ros Vickers is a Lecturer of Law at Charles Darwin University. She is the Northern Territory editor of the Australian Environmental Law Review.

${ }^{* * *}$ Ken Parish is a Senior Lecturer of Law at Charles Darwin University. He pioneered and oversaw the implementation and development of CDU's online law degree program starting in 2003.

${ }^{1}$ W Binford, 'Envisioning a Twenty-First Century Legal Education', (2013) 43 UJLEPik'y 157.
} 
In responding to this challenge, Martin Barry, Dubin and Joy, when considering how clinical legal education should adapt to the digital age, noted:

Aside from influencing the place of clinical education in the new millennium, technological advances will affect the forms of clinical education by making possible new and different teaching and service opportunities and clinical models. ${ }^{2}$

While only an idea in 2000 , the ability of law students to undertake a clinical unit while studying fully online has become a reality in at least one Australian law school; Charles Darwin University ('CDU'). How this clinical unit fits within the evolution of clinical legal education is discussed, as is the evolution of online legal education more broadly. The risks and rewards of online legal education, and online clinical legal education in particular, are canvassed, and the structure of the CDU clinical unit is explained.

Binford has suggested that advances in digital technology have ushered in a new age in legal education. ${ }^{3}$ We agree and it can be anticipated that clinical opportunities for those studying law fully online will continue to evolve not only in Australia, but also in other countries. It is hoped that the experiences of an early adopter of online clinical legal education will assist others considering a similar path.

\footnotetext{
2 M Martin Barry, J Dubin, P Joy, 'Clinical Education for this Millennium: The Third Wave' (2001) 7 Clinical L Rev 1 at 53.

${ }^{3}$ W Binford, 'Envisioning a Twenty-First Century Legal Education', (2013) 43 UJLEP Pik'y 157 at 180.
} 


\section{The evolution of clinical legal education}

The role of communication and information technologies in clinical legal education must be considered in the context of the evolution of clinical legal education. The latter is a well-trodden path and, therefore, the treatment of the topic in this paper will be brief. $^{4}$

An early iteration of clinical legal education was that conceptualised by the American academic, legal philosopher and jurist, Jerome Frank, in the 1930s. ${ }^{5}$ While not the first call for a change to the way law was taught in American law schools, ${ }^{6}$ Frank is recognised as a leader of the legal realist movement and a pioneer in the cause of clinical legal education. ${ }^{7}$

\footnotetext{
${ }^{4}$ Generally, see J Frank, 'Why Not a Clinical Law School?' (1933) 81 U Pa L Rev 907; G Grossman, 'Clinical Legal Education: History and Diagnosis' (1974) 26 J Leg Ed 162; J Giddings, 'Contemplating the Future of Clinical Legal Education' (2008) 17 Griffith L Rev 1; M Martin Barry, J Dubin, P Joy, 'Clinical Education for this Millennium: The Third Wave' (2001) 7 Clinical L Rev 1; J Giddings, R Burridge, S Gavigan, C Klein, 'The First Wave of Modern Clinical Legal Education: The United States, Britain, Canada and Australia' in The Global Clinical Movement: Educating Lawyers for Social Justice (F Bloch ed, OUP, 2011) Ch 1.

5 J Frank, 'Why Not a Clinical Law School?' (1933) 81 U Pa L Rev 907 at 917-918. See also G Grossman, 'Clinical Legal Education: History and Diagnosis' (1974) 26 J Leg Ed 162 at 169.

${ }^{6}$ Martin Barry, Dubin and Joy note that as early as 1917, William Rowe "advocated "law school based clinical legal education as the best way to train law students to become competent lawyers": M Martin Barry, J Dubin, P Joy, 'Clinical Education for this Millennium: The Third Wave' (2001) 7 Clinical L Rev 1 at 6. See also W Rowe, 'Legal Clinics and Better Trained Lawyers - A Necessity' (1917) 11 Ill L Rev 591. In Russia, the call for change sounded 16 years earlier. Wilson notes that "as early as 1901 clinical legal education was proposed by a Russian professor, Alexander Lyublinsky, who believed that a law school clinical component could be modelled on medical training": R Wilson, 'Training for Justice: the Global Reach of Clinical Legal Education' (2004) 22 Penn St Int'l L Rev 421.

${ }^{7}$ M Martin Barry, J Dubin, P Joy, 'Clinical Education for this Millennium: The Third Wave' (2001) 7 Clinical L Rev 1 at 8; G Grossman, 'Clinical Legal Education: History and Diagnosis' (1974) 26 J Leg Ed 162 at 168-169.
} 
Concerned about the prevalence of a 'library law' approach to legal education based on Dean Christopher Columbus Langdell's casebook method of law teaching, ${ }^{8}$ Frank, influenced by the teaching method employed in medical schools, ${ }^{9}$ advocated for the establishment of legal clinics in law schools run by academic staff and assisted by graduate students, undergraduate students, and leading members of the legal profession. Such clinics "would be done for little or no charge", ${ }^{10}$ and the "teacherclinicians would devote their full time to their teaching, including such clinical work, and would not engage in private practice" ${ }^{11}$

It was not until the 1960s, and the establishment of the Council on Education in Professional Responsibility (COEPR), that "clinical legal education solidified and expanded its foothold in the academy"12 through the "establishment of law clinics at a number of law schools". ${ }^{13}$ These early clinics focused on legal service delivery, usually to disadvantaged members of the community. According to Grossman, community service, rather than educational benefit, was the main objective. ${ }^{14}$

\footnotetext{
${ }^{8}$ J Frank, 'Why Not a Clinical Law School?' (1933) 81 U Pa L Rev 907 at 908.

9 J Frank, 'Why Not a Clinical Law School?' (1933) 81 U Pa L Rev 907 at 917.

${ }^{10}$ J Frank, 'Why Not a Clinical Law School?' (1933) 81 U Pa L Rev 907 at 917.

${ }^{11}$ J Frank, ‘Why Not a Clinical Law School?' (1933) 81 U Pa L Rev 907 at 917.

${ }^{12}$ M Martin Barry, J Dubin, P Joy, 'Clinical Education for this Millennium: The Third Wave' (2001) 7 Clinical L Rev 1 at 12.

${ }^{13}$ G Grossman, 'Clinical Legal Education: History and Diagnosis' (1974) 26 J Leg Ed 162 at 172-173.

${ }^{14}$ G Grossman, 'Clinical Legal Education: History and Diagnosis' (1974) 26 J Leg Ed 162 at 174.
} 
In the early evolution of clinical legal education, the distinction between in-house clinics located in, or run by, the law school, and externships, was not pronounced. Grossman, writing in 1974, noted:

The format of service-orientated clinical programs generally involves the farming out of students to various community law offices... At the law offices students work under the supervision of a staff attorney. A member of the law faculty or a clinical appointee is also responsible for supervision from the law school-at least on a part-time basis. A classroom component may be added to the program to orient students at the start and/or to take stock of their experiences during or after their field work. ${ }^{15}$

The clinical legal education movement was not confined to the United States. As Giddings notes, "countries including Australia, Canada, Chile, England, India, South Africa, the United States and Zimbabwe saw the development of clinical programs in the 1960 s and $1970 \mathrm{~s}^{\prime \prime} .{ }^{16}$ Whether in-house or 'farmed out', clinical legal education in the 1960s and 1970s focused on caseload management and service delivery to real clients in a law office setting.

Today, clinical legal education is truly global in scope, ${ }^{17}$ and takes a variety of forms. In addition to real-client clinics, law students around the world are involved in raising

\footnotetext{
${ }^{15}$ G Grossman, 'Clinical Legal Education: History and Diagnosis' (1974) 26 J Leg Ed 162 at 175.

${ }^{16} \mathrm{~J}$ Giddings, 'Contemplating the Future of Clinical Legal Education' (2008) 17 Griffith L Rev 1 at 2. See also R Wilson, 'Training for Justice: the Global Reach of Clinical Legal Education' (2004) 22 Penn St Int'l L Rev 421 at 421-422; J Giddings, R Burridge, S Gavigan, C Klein, 'The First Wave of Modern Clinical Legal Education: The United States, Britain, Canada and Australia' in The Global Clinical Movement: Educating Lawyers for Social Justice (F Bloch ed, OUP, 2011) Ch 1.

${ }^{17}$ As evidenced by organisations such as the Global Alliance for Justice Education (www.gaje.org), and the International Journal of Clinical Legal Education (www.ijcle.com). Generally see F Bloch, 'Access to Justice and the Global Clinical Movement' (2008) 28 Wash U J L \& Pol'y 111; The Global Clinical Movement: Educating Lawyers for Social Justice (F Bloch ed, OUP, 2011) Pt 1.
} 
community awareness of legal rights through Street Law programs, ${ }^{18}$ legal policy formulation through externships at law reform bodies and government agencies, ${ }^{19}$ and learning professional ethics and practice skills thorough simulations. ${ }^{20}$

According to Milstein, clinical legal education is defined by the educational outcome achieved, rather than by the existence of a 'client' in the process. He divides clinical legal education into three branches; in-house real-client clinics, ${ }^{21}$ externships, and simulations.

Not all would agree with Milstein's broad definition of clinical programs. Evans, for example, takes a more traditional view when he describes a clinic as "supervised experiential encounters between clients and their legal advisors, in the interest of just case outcomes, the processes of law reform and political renewal".22 One of the authors of this article, relying on the work of Rice and Coss, ${ }^{23}$ previously distinguished clinical from other forms of legal education based on the following: ${ }^{24}$

\footnotetext{
${ }^{18}$ For a description of Street Law, see www.streetlaw.org. See also R Grimes, D McQuoid-Mason, E O'Brien, J Zimmer, 'Street Law and Social Justice Education' in The Global Clinical Movement: Educating Lawyers for Social Justice (F Bloch ed, OUP, 2011) Ch 15.

${ }^{19}$ See L McCrimmon, E Santow, 'Justice Education, Law Reform, and the Clinical Method' in The Global Clinical Movement: Educating Lawyers for Social Justice (F Bloch ed, OUP, 2011) Ch 14.

${ }^{20}$ See N Duncan, S Kay, 'Addressing Lawyer Competence, Ethics, and Professionalism' in The Global Clinical Movement: Educating Lawyers for Social Justice (F Bloch ed, OUP, 2011) Ch 12.

${ }^{21}$ We prefer the term 'real-client' rather than 'live-client' when describing the nature of an in-house clinic.

${ }^{22}$ A Evans, 'Global Agendas, Cultural Capital, and Self-assessment of Clinical Legal Education Programs' (2012) 38 Monash U L Rev 55 at 59. See also R Wilson, 'Training for Justice: the Global Reach of Clinical Legal Education' (2004) 22 Penn St Int'l L Rev 421 at 422-423.

${ }^{23}$ S Rice, G Coss, A Guide to Implementing Clinical Teaching Method in the Law School Curriculum (Sydney, Centre for Legal Education, 1996).

${ }^{24}$ L McCrimmon, Mandating a Culture of Service: Pro Bono in the Law School Curriculum (20032004) 14 Legal Ed Rev 53 at 57.
} 
- $\quad$ the presence of a real client in the student's activities;

- $\quad$ a focus on ethics and professionalism, social needs and the lawyer's role in society, rather than development of legal skills competency; and

- $\quad$ emphasis on community service to people with legal need but without the resources to address the need to a sufficient degree or at all.

Based on these criteria, the absence of a client disqualifies a program from being described as 'clinical'. Pro bono placements, simulations, and externships that do not involve advice to, and representation of, a real client would not qualify as a clinical program.

While historically the existence of a client in the law student's activities was critical to a determination of whether the activity could be considered 'clinical', the primary focus of clinical legal education has shifted to place a greater emphasis on the student's learning experience. ${ }^{25}$ While community service through assisting disadvantaged members of society is still an important component of most clinical programs, we agree with Giddings that,

clinical teaching can be usefully characterised by way of a clinical continuum which relates to the degree of control exercised over the teaching setting. The emphasis on critique and reflection is a constant while control over the environment varies. ${ }^{26}$

While the clinical program at Charles Darwin University ('CDU') does not include stand-alone legal skills units such as Trial Advocacy and Alternate Dispute Resolution

\footnotetext{
${ }^{25}$ For example see R Wilson, 'Training for Justice: the Global Reach of Clinical Legal Education' (2004) 22 Penn St Int'l L Rev 421 at 424.

${ }^{26}$ J Giddings, 'A Circle Game: Issues in Australian Clinical Legal Education' (1999) 10 Legal Ed Rev 33 at 35 .
} 
within its definition of clinical offerings, we do apply a broader definition of 'client' than that used by Evans, Rice and Coss. For example, a student externship at an independent law reform body whose notional 'client' is usually broadly defined as a state or federal government would warrant the designation of a 'clinical placement'. Further, if a student was placed in the legal policy unit of a community legal centre, ${ }^{27}$ such a placement would still be considered 'clinical' notwithstanding that the student would not interact directly with the centre's clients. Finally, law students involved in a Street Law unit would, at least as we apply the definition, be considered a clinical legal education program. ${ }^{28}$

This broad definition of clinical legal education sits comfortably with the concept at a global level. The fact that clinical legal education can now be described as a global movement is evidenced by a number of sources, including:

- $\quad$ the large number of transnational collaborations among clinicians from different parts of the world;29

- the existence of truly global organisations such as the Global Alliance for Justice Education ('GAJE') ${ }^{30}$ which, at its $8^{\text {th }}$ Worldwide Conference held

\footnotetext{
${ }^{27}$ The ability of community legal centres to engage in policy work has decreased significantly in Australia since 1 July 2014 as a result of the actions of the Commonwealth government prohibiting legal centres receiving Commonwealth government funding from using such funds for law reform projects: see http://www.lawyersweekly.com.au/news/15506-ala-slams-ban-on-clc-advocacy (accessed 27 September 2016).

${ }^{28}$ For a description of Street Law, see www.streetlaw.org. See also R Grimes, D McQuoid-Mason, E O'Brien, J Zimmer, 'Street Law and Social Justice Education' in The Global Clinical Movement: Educating Lawyers for Social Justice (F Bloch ed, OUP, 2011) Ch 15.

${ }^{29}$ The Global Clinical Movement: Educating Lawyers for Social Justice (F Bloch ed, OUP, 2011) Pt I; F Bloch, 'Access to Justice and the Global Clinical Movement' (2008) 28 Wash U J L \& Pol'y 111 at 116.

${ }^{30}$ For a discussion of the history of GAJE see E Santow, G Mukundi Wachira, 'The Global Alliance for Justice Education' in The Global Clinical Movement: Educating Lawyers for Social Justice (F Bloch ed, OUP, 2011) Ch 25.
} 
in Eskişehir, Turkey in July 2015, attracted 350 delegates $^{31}$ (most of whom were clinicians) from all regions of the world;

the ever-increasing incorporation of clinical teaching methodology in law school curricula worldwide; ${ }^{32}$ and

- $\quad$ legal publications dedicated to fostering international clinical legal education, the most prominent being the International Journal of Clinical Legal Education published in the United Kingdom, ${ }^{33}$ and the book, The Global Clinical Movement: Educating Lawyers for Social Justice edited by Professor Frank Bloch (OUP, 2011).

While the content of a clinical legal education program can differ between countries, and between universities within the same country, Bloch suggests that the clinical dimension of any program has common features.

To begin, three elements stand out as constituting the most important commonly conceived notions of clinical legal education around the world: professional skills training, experiential learning, and instilling professional values of public responsibility and social justice. These three elements interact, with varying degrees of emphasis, to form the core of a global conception of clinical legal education. Although they can be described separately, they often are interdependent, and each can influence how the others are conceived and implemented. ${ }^{34}$

\footnotetext{
${ }^{31}$ The number of delegates had to be capped at 350 due to venue capacity.

${ }^{32}$ For example see The Global Clinical Movement: Educating Lawyers for Social Justice (F Bloch ed, OUP, 2011) Pt I; F Bloch, 'Access to Justice and the Global Clinical Movement' (2008) 28 Wash U J L \& Pol'y 111; Y Cai, 'Global Clinical Legal Education and International Partnerships: A Chinese Legal Educator's Perspective' (2011) 26 Md J Int'l L 159; S Rosenbaum, 'The Legal Clinic is More Than a Sign on the Door: Transforming Law School Education in Revolutionary Egypt' (2012) 5 Berkley J Middle E $\mathcal{E}$ Islamic L 39; B Lasky, N Nazeri, 'the Development and Expansion of University-based Community/Clinical Legal Education Programs in Malaysia: Means, Methods, Strategies' (2011) 16 Int'l J Clinical Legal Educ 59.

${ }^{33}$ See www.northumbriajournals.co.uk/index.php/ijcle (accessed 27 September 2016).

${ }^{34} \mathrm{~F}$ Bloch, 'Access to Justice and the Global Clinical Movement' (2008) 28 Wash U J L E Pol'y 111 at 121.
} 
It follows that, in a global context, the concept of clinical legal education is broader than that espoused by Evans and others, discussed above. The absence of a client in the process would not disqualify a program from being designated as 'clinical'. Further, it is broader than that three branches of clinical legal education identified by Milstein; ${ }^{35}$ in-house real-client clinics, externships, and simulations.

In particular, the involvement of law students in many Street Law programs, which are expanding rapidly in Central and South America, Eastern Europe, Africa, the Middle East and Asia, ${ }^{36}$ would warrant designation as a clinical program. We agree with Bloch who has observed that the diversity of clinical programs has contributed to its richness worldwide. ${ }^{37}$

\section{Online legal education}

\section{Definitions}

The definition of online legal education, like clinical legal education more broadly, warrants consideration. What constitutes an online course varies, depending on the

\footnotetext{
${ }^{35}$ E Milstein, 'Clinical Legal Education in the United States: In-House Clinics, Externships, and Simulations' (2001) 51 J Legal Educ 375 at 376.

${ }^{36}$ For example see B Lasky, N Nazeri, 'the Development and Expansion of University-based Community/Clinical Legal Education Programs in Malaysia: Means, Methods, Strategies' (2011) 16 Int'l J Clinical Legal Educ 59 at 63; R Grimes, D McQuoid-Mason, E O'Brien, J Zimmer, 'Street Law and Social Justice Education' in The Global Clinical Movement: Educating Lawyers for Social Justice (F Bloch ed, OUP, 2011) Ch 15; A Pandey, S Shukkur, 'Legal Literacy Projects: Clinical Experience of Empowering the Poor in India' in The Global Clinical Movement: Educating Lawyers for Social Justice (F Bloch ed, OUP, 2011) Ch 16.

${ }^{37}$ Bloch, 'Access to Justice and the Global Clinical Movement' (2008) 28 Wash U J L \& Pol'y 111 at 115.
} 
mode of distance learning used. The term 'distance learning' can be defined as "communication which connects instructors and students who are separated by geography and, often, time". ${ }^{38}$

As Twining reminds us, "distance learning or distance education are relatively new names for long-established practices that have gone by less enticing titles, such as correspondence courses and external degrees". ${ }^{39}$ In the context of legal education, such programs can trace their roots to at least the mid-nineteenth century. The University of London External LLB, which is still offered, ${ }^{40}$ started in 1850 and has been available to international students since $1858 .{ }^{41}$

The concept of e-learning can be defined as "learning facilitated and supported through the use of information and communication technologies". ${ }^{42}$ Online, or elearning, legal education "involves the use of information, communication and instructional technologies to enhance students' learning of the law and to provide law teachers with environments and tools for teaching the law". ${ }^{43}$ Through the use of

\footnotetext{
${ }^{38}$ H Leskovac, 'Distance Learning in Legal Education: Implications of Frame Relay Videoconferencing' (1998) 8 Alb L J Sci \& Tech 305 at 309. See also M Perlin, 'An Internet-Based Mental Disability Law Program: Implications for Social Change in Nations with Developing Economies' (2006-2007) 30 Fordham Int'l L J 435 at 439.

${ }^{39}$ W Twining, 'Developments in Legal Education: Beyond the Primary School Model' (1990-1991) 2 Legal Ed Rev 35 at 45.

${ }^{40}$ See www.londoninternational.ac.uk/llb (accessed 27 September 2016).

${ }^{41}$ W Twining, 'Developments in Legal Education: Beyond the Primary School Model' (1990-1991) 2 Legal Ed Rev 35 at 45.

${ }^{42}$ S Bloxham, 'Widening Access and the Use of ICT in Legal Education' (2005) 39 Law Teacher 93 at 99.

${ }^{43}$ P Maharg, A Muntjewerff, 'Through a Screen Darkly; Electronic Legal Education in Europe' (2002) 36 Law Teacher 307.
} 
online systems software such as Blackboard Learn ${ }^{44}$ and Moodle ${ }^{45}$ (to name but two), students can undertake degree programs without ever setting foot on a university campus.

Online learning can be either synchronous or asynchronous, or a combination of the two. Synchronous e-learning takes place when all participants are interacting at the same time, commonly supported by audio and videoconferencing software such as Skype, virtual classrooms such as Blackboard Collaborate, ${ }^{46}$ and chat facilities in the online systems software. Asynchronous e-learning occurs when teachers and students are not online at the same time, and is commonly supported by email, discussion boards, wikis, blogs, podcasts and audio recordings which students can access at a time that suits them. ${ }^{47}$

\footnotetext{
${ }^{44}$ Blackboard Learn is a virtual learning environment and course management system developed by Blackboard Inc. As at the date of writing this article, it was the most widely used Leaning Management System used by law schools in Australia. For a general discussion of Blackboard Learn, see www.blackboard.com/learning-management-system/blackboard-learn.aspx (accessed 27 September 2016), or en.wikipedia.org/wiki/Blackboard Learn (accessed 27 September 2016). ${ }^{45}$ Moodle is a free, open source, Learning Management System. Generally see https://moodle.org (accessed 27 September 2016); en.wikipedia.org/wiki/Moodle (accessed 27 September 2016). Moodle was originally an acronym for "modular object-orientated dynamic learning environment": https://en.wikipedia.org/wiki/Moodle (accessed 7 January 2016).

${ }^{46}$ For a description of Blackboard Collaborate see www.blackboard.com/online-collaborativelearning/index.aspx (accessed 27 September 2016).

${ }^{47}$ Generally see S Hrastinski, 'Asynchronous \& Synchronous E-Learning' (2008, No 4) Educause Quarterly 51 at 51-52; https://en.wikipedia.org/wiki/Educational_technology (accessed 27 September 2016); Evaluation of Evidence-Based Practices in Online Learning: A Meta-Analysis and Review of Online Learning Studies (US Department of Education Office of Planning, Evaluation, and Policy Development Policy and Program Studies Service, September 2010) at 4.
} 


\section{Why online legal education?}

As Noam observes, the lecture method of face-to-face teaching, which requires the physical aggregation of students in one place, "remained remarkably stable for 2,500 years". ${ }^{48}$ Noam argues that, with the advent of information and communication technologies, the predominant paradigm is breaking down.

The reason is not primarily technological. Technology simply enables change. The first fundamental reason is that the production of information has undermined the traditional university structure, making it ready to implode once alternatives to its function become possible. ${ }^{49}$

Another factor placing strain on the traditional mode of face-to-face teaching is the increasing demand on a law student's time. Gone are the days, at least in Australia and we suspect elsewhere, when most law students studied full-time and worked only in the university breaks. Today, students juggle a variety of commitments; work (often full-time), family and social. An increasing number of students want to study at a time and in a place that suits them, not at a time and in a place mandated by the university.

For students living in rural, remote and regional centres without a tertiary institution, undertaking a degree online is a viable, and often the only, way to attend university. In Australia, students living in such areas are less likely to attend university than those living in larger cities. ${ }^{50}$ This is due to a number of factors, including the comparatively

\footnotetext{
48 E Noam, 'Electronics and the Future of Law Schools' (2008) 17 J Contemp Legal Issues 51 at 52-53.

${ }^{49}$ E Noam, 'Electronics and the Future of Law Schools' (2008) 17 J Contemp Legal Issues 51 at 53.

${ }^{50}$ D Kemp, A Norton, Review of the Demand Driven Funding System (Australian Government, 2014) at [4.4].
} 
greater number of students from low socioeconomic backgrounds in regional and remote areas, ${ }^{51}$ lower secondary school completion rates and lower university entrance scores. These factors make it more difficult for students from rural, remote and regional centres to move to larger cities to attend university. ${ }^{52}$ As Kemp and Norton note, "[l]ong distances to campuses create logistical problems in getting to a higher education provider for many people outside the major urban centres. Leaving home to study adds to the total cost of education". ${ }^{53}$

The low tech, lecture based, system of education often venerated by the baby-boomer generation ${ }^{54}$ also no longer resonates with students in the Digital Age. ${ }^{55}$ As Rosenberg suggests:

As the presence of technology becomes increasingly ubiquitous and user-friendly, and the lives of our students are inextricably linked with technology, we should embrace the potential of online learning to enhance the quality of our teaching, the learning

\footnotetext{
${ }^{51}$ Australian Government Department of Education, Employment and Workplace Relations, Regional Participation: The Role of Socioeconomic Status and Access (Commonwealth of Australia, 2010) at 4.

${ }^{52}$ D Kemp, A Norton, Review of the Demand Driven Funding System (Australian Government, 2014) at [4.4].

${ }^{53}$ D Kemp, A Norton, Review of the Demand Driven Funding System (Australian Government, 2014) at [4.4]. See also, Australian Government Department of Education, Employment and Workplace Relations, Regional Participation: The Role of Socioeconomic Status and Access (Commonwealth of Australia, 2010) at 6.

${ }^{54}$ The term 'baby boomer generation' in an Australian context refers to people born post-World War II approximately between the years 1946 and 1965, giving an age range between 50 and 70 as of 2016: ABS Newsletter 4914.0.55.001 at www.abs.gov.au (accessed 27 September 2016); Macquarie Concise Dictionary (4th $e d, 2006)$ at 76.

${ }^{55}$ The 'Digital Age' is "defined as the time period starting in the 1970s with the introduction of the personal computer with subsequent technology introduced providing the ability to transfer information freely and quickly": see www.yourdictionary.com/digital-age (accessed 27 September 2016). See also Cambridge Dictionary online at: www.dictionary.cambridge.org/dictionary/english/digital-age (accessed 27 September 2016).
} 
experience of our students, and most importantly, how effectively we prepare students for the challenge of lawyering in the twenty-first century. ${ }^{56}$

The transmission of information and ideas is not the exclusive purview of face-to-face teaching. This can be done as effectively online. ${ }^{57}$ Further, as e-learning systems software continues to improve the comparative advantage enjoyed by face-to-face law school instruction - namely, mentoring, teacher/student and student/student engagement, and skills training - diminishes. For example, since 2010 law students studying online at CDU have been able to complete skills units such as trial advocacy and dispute resolution, and, through the use of Blackboard Collaborate, can interact with staff and other students synchronously online. As Binford has noted:

The world that twentieth century law professors know is no more. Fortunately, we stand at a crossroads where we have an opportunity to build a new one. This is our Gutenberg moment. ${ }^{5}$

The reference to Gutenberg is informative. A technological revolution was ushered in by Gutenberg's invention of mechanical moveable type..$^{59}$ In the words of McLuhan, "[t]he mechanical printed page was crossed with a new organic form that changed

\footnotetext{
${ }^{56} \mathrm{~J}$ Rosenberg, 'Confronting Cliches in Online Instruction: Using a Hybrid Model to Teach Lawyering Skills' (2008-2009) 12 SMU Sci \& Tech L Rev 19 at 82.

${ }^{57}$ E Noam, 'Electronics and the Future of Law Schools' (2008) 17 J Contemp Legal Issues 51 at 61-62; Evaluation of Evidence-Based Practices in Online Learning: A Meta-Analysis and Review of Online Learning Studies (US Department of Education Office of Planning, Evaluation, and Policy Development Policy and Program Studies Service, September 2010) at xviii.

${ }^{58}$ W W Binford, 'Envisioning a Twenty-first Century Legal Education' (2013) 43 Wash U J L \& Policy 157 at 180.

${ }^{59}$ Whether Gutenberg invented movable type is questionable. As Briggs and Burke note: "In the early fifteenth century ... the Koreans invented a form of movable type with what has been described by the French scholar Henri-Jean Martin as 'an almost hallucinatory similarity to Gutenberg's'": A Briggs, P Burke, A Social History of the Media: From Gutenberg to the Internet, (Polity Press, 2002) at 15.
} 
layout as it changed politics and society". ${ }^{60}$ While it is too early to ascertain whether the advent of the Digital age will mark a comparable milestone in human political and social evolution, there are some interesting parallels between the advent of the printing press and the rapid development of the internet and its offshoot, online education. Of particular note in the context of this article is the ongoing resistance of admissions bodies in recognising law degree programs offered fully online, and of academics in engaging with digital technologies.

As Briggs and Burke note, "the triumphalist accounts of [Gutenberg's] invention were matched by what we might call catastrophist narratives". ${ }^{61}$ Those whose perceived self-interest was affected by the new technology - publishers of hand-written texts, and the churchman and wealthy who enjoyed a virtual monopoly on literacy - did not embrace the printing revolution. ${ }^{62}$ This notwithstanding, the gradual ubiquity of the printing press was a catalyst for change, ${ }^{63}$ and it can be anticipated that both the use of, and rapid advancements in, digital technology in the twenty-first century will

\footnotetext{
${ }^{60}$ M McLuhan, The Guttenberg Galaxy (10th ed, 2010, University of Toronto Press) at 129.

${ }^{61}$ A Briggs, P Burke, A Social History of the Media: From Gutenberg to the Internet, (Polity Press, 2002) at 17.

${ }^{62}$ A Briggs, P Burke, A Social History of the Media: From Gutenberg to the Internet, (Polity Press, 2002) at $17-18$.

${ }^{63}$ Briggs and Burke noted that adaption of the new print medium was gradual, and posited whether "a revolution which is not rapid can be regarded as a revolution at all": A Briggs, P Burke, A Social History of the Media: From Gutenberg to the Internet, (Polity Press, 2002) at 22.
} 
result in significant changes both to the way law students are taught and to the way they learn. ${ }^{64}$

Further (as occurred in the decades following Gutenberg's invention ${ }^{65}$ ), today not everyone embraces the digital revolution in learning and teaching occurring at this early stage of the twenty-first century. The ability of students to complete their undergraduate law degree fully online is actively discouraged in some jurisdictions. In the United States, for example, Standard 306 of the American Bar Association's ('ABA') Standards and Rules for Approval of Law Schools denies accreditation to any law school that provides a Juris Doctor ('JD') degree fully by distance education. ${ }^{66}$ As the ABA warns would-be lawyers on its website, "earning an education completely via distance education may drastically limit your ability to sit for the bar in many states" ${ }^{67}$ Despite such a significant deterrent, a number of unaccredited law schools offer online JD degrees, with graduates who wish to practice law sitting the bar exam in jurisdictions, such as California, which permit them to do so. ${ }^{68}$

\footnotetext{
${ }^{64}$ Flood opines that technology will have a profound effect on legal education, but goes on to note that "it has not occurred yet": J Flood, 'Global Challenges for Legal Education: Competing for the World's Law Students' (2015) 24 Nottingham L J 79 at 87.

${ }^{65}$ While the printing press was embraced by Europeans, the Orthodox Christian and Muslim worlds resisted the new technology: A Briggs, P Burke, A Social History of the Media: From Gutenberg to the Internet, (Polity Press, 2002) at 16-17.

${ }^{66}$ Generally see http://www.americanbar.org/groups/legal_education/resources/distance_education.html (accessed 27 September 2016).

${ }^{67}$ www.americanbar.org/groups/legal education/resources/distance education.html (accessed 27 September 2016).

${ }^{68}$ S Bennett, 'Distance Learning in Law' (2014) 38 Seaton Hall Legis J 1 at 3.
} 
The resistance to online legal education from within law schools also cannot be underestimated. Many legal academics are reluctant to embrace new teaching approaches and methods. As Martin Barry, Dubin and Joy noted, "law faculty are extremely adept at resisting changes in legal education that 'disrupt the comfort of life within the institution' or are otherwise contrary to self-interest" ${ }^{\prime 69}$

Fortunately for proponents of online legal education and law students in Australia, the governing admissions body, the Law Admissions Consultative Committee ('LACC'), has adopted a different, more enlightened, view. LACC is the national body which sets the academic requirements for the admission of Australian lawyers, and is made up of representatives from the law admission authorities in each Australian jurisdiction, the Committee of Australian Law Deans, the Australian Professional Legal Education Council and the Law Council of Australia. ${ }^{70}$

This is not to suggest that LACC has been unconcerned about the proliferation of online LLB and JD programs offered by Australian universities. To accept a change in the status quo, LACC had to be convinced that a fully online law degree program was not a diluted version of the standard law curriculum taught face-to-face. In February 2012, LACC invited Professor Les McCrimmon from CDU and Professor Stephen Colbran, then from the University of New England, to address committee members

\footnotetext{
${ }^{69}$ M Martin Barry, J Dubin, P Joy, 'Clinical Education for this Millennium: The Third Wave' (2001) 7 Clinical L Rev 1 at 52, quoting from R Uphoff, J Clark, E Monhan, 'Preparing the New Law Graduate to Practice Law: A View From the Trenches' (1997) 65 U Cin L Rev 381 at 421.

${ }^{70}$ Generally see www.lawcouncil.asn.au/LACC (accessed 27 September 2016).
} 
on the teaching of law in the digital learning environment. Subsequently, LACC was satisfied that the educational and professional standards it sets can be achieved through a fully online degree program. For the purposes of admission to legal practice in Australia, therefore, no distinction is made by Australian admission authorities between students who have completed their law degree fully online and those who were taught on-campus.

In 2015, there were 36 law schools in Australia. A small, but increasing, number offer LLB and/or JD programs fully online. ${ }^{71}$ Writing in 2013, Emeritus Professor David Weisbrot, a former Dean of Sydney University Law School, noted that:

A generation ago, distance education was seen as the poor cousin ... This has all changed enormously with the revolution in information and communications technology, which permits access to high-quality online materials, more regular contact and interactive discussions with staff and fellow students, and virtually limitless online access to legal and research materials. ${ }^{72}$

While online legal education is gaining in popularity in Australia, the inclusion of a clinical legal education unit as part of an online degree is still in its infancy. Of the law schools offering a fully on-line law degree, only CDU offers external students the opportunity to undertake a clinical unit for credit. Another online law degree provider, Central Queensland University ('CQU'), is developing clinical opportunities

\footnotetext{
${ }^{71}$ As at the end of 2015, an LLB or JD could be obtained fully online at 7 Australian universities: Charles Darwin University, University of New England, Southern Cross University, University of Southern Queensland, Central Queensland University, Edith Cowan University, RMIT (through Open Universities Australia).

72 D Weisbrot, So You Want to be a Lawyer (Acer Press, 2013) at 49.
} 
for students, but as at the date of writing, this program is at a very early stage of development. Students enrolled in Civil Procedure and Employment Law at CQU have the opportunity to log in via the Zoom Web-conferencing Service ${ }^{73}$ to observe online client interviews conducted by legal practitioners in partner legal centres, but CQU is not yet at the stage of allowing students to provide legal advice under supervision. Over the next five years, CQU plans to embed clinical opportunities for students into substantive law units, although such opportunities are still being developed.

As shall be discussed in greater detail below, an online component of a clinical legal education program changes the way in which students interact with clinical faculty, other students working on the same project, and a client (if there is one). Such interaction involves the use of information, communication and instructional technologies to facilitate the unit's educational objectives; and in particular the process by which students reflect on their experiences. The way in which clinical faculty interact with site supervisors at the clinic or placement also is affected.

\section{Rewards and risks of online education}

An assessment of the rewards and risks of any form of education is often subjective, influenced significantly by the way those making the assessment were taught, the

\footnotetext{
${ }^{73}$ For a discussion of the Zoom Web Conferencing Service see: https://zoom.us.
} 
stereotypes to which the assessor subscribes, ${ }^{74}$ and the degree of self-interest involved in the assessment. Generally, however, the perceived rewards and risks of online education tend to be described as follows. ${ }^{75}$

Table 1 - Rewards and risks of online learning

\begin{tabular}{|c|c|}
\hline Rewards & Risks \\
\hline $\begin{array}{l}\text { Overcoming the constraints of space, time } \\
\text { and distance. }\end{array}$ & $\begin{array}{l}\text { The impersonal nature of computer } \\
\text { mediated communication leading to a } \\
\text { feeling of isolation in both the student and } \\
\text { the teacher. }\end{array}$ \\
\hline $\begin{array}{l}\text { Broadening access to higher education to } \\
\text { those who, for a variety of reasons including } \\
\text { cost, employment and family } \\
\text { responsibilities, and where they live, cannot } \\
\text { attend classes at a set time or place. }\end{array}$ & $\begin{array}{l}\text { The cost in human and financial resources in } \\
\text { establishing and maintaining online } \\
\text { learning. }{ }^{76}\end{array}$ \\
\hline $\begin{array}{l}\text { Providing an environment where students, } \\
\text { and in particular mature aged students, feel } \\
\text { they belong. }\end{array}$ & $\begin{array}{l}\text { The loss to the student of the 'on-campus } \\
\text { experience'. }{ }^{77}\end{array}$ \\
\hline $\begin{array}{l}\text { Encouraging innovation in the way students } \\
\text { learn, and in the way academics teach, } \\
\text { through the use of an ever increasing array } \\
\text { of educational tools. }\end{array}$ & $\begin{array}{l}\text { The negative impact online learning has on } \\
\text { the traditional paradigm of the classroom } \\
\text { and the academy. }\end{array}$ \\
\hline
\end{tabular}

${ }^{74}$ E Noam, 'Electronics and the Future of Law Schools' (2008) 17 J Contemp Legal Issues 51 at 61.

${ }^{75}$ Generally see: E Noam, 'Electronics and the Future of Law Schools' (2008) 17 J Contemp Legal Issues 51 at 61-62; J Rosenberg, 'Confronting Cliches in Online Instruction: Using a Hybrid Model to Teach Lawyering Skills' (2008-2009) 12 SMU Sci \& Tech L Rev 19 at 19-21.

${ }^{76}$ For example, see J Flood, 'Global Challenges for Legal Education: Competing for the World's Law Students' (2015) 24 Nottingham L J 79 at 86.

${ }_{77}$ While everyone's 'campus experience' is different, this includes such things as discussion on academic subjects both in and outside of class, involvement in law school and campus activities such as clubs and sporting events, and, through face-to-face interaction making new, and sometimes lifelong, friends. 
As the following discussion illustrates, most of the above-noted rewards and risks of online teaching have merit. Whether the advantages of implementing a fully online degree outweigh the disadvantages depends on a number of factors, perhaps the most important being the law school's physical location. Generally, at least in Australia at this early stage of the development of online legal education, law schools located in regional centres have more to gain from implementing an online degree program than established law schools in major cities.

In this assessment of the rewards and risks of online legal education, it is important to note that the authors of this article cannot be described as either 'enthusiasts' or 'naysayers' when it comes to online legal education. According to Rosenberg, 'enthusiasts' are "true believers in technology, and they are certain the future has arrived with online classes, programs, and universities that promise, and deliver, a cure for much of what ails the modern education enterprise". ${ }^{78}$ 'Naysayers', by contrast, are "sceptical of any technology that interferes with face-to-face human interaction, and they worry about the danger of online learning". ${ }^{79}$

\footnotetext{
${ }^{78} \mathrm{~J}$ Rosenberg, 'Confronting Cliches in Online Instruction: Using a Hybrid Model to Teach Lawyering Skills' (2008-2009) 12 SMU Sci \& Tech L Rev 19 at 20.

${ }^{79} \mathrm{~J}$ Rosenberg, 'Confronting Cliches in Online Instruction: Using a Hybrid Model to Teach Lawyering Skills' (2008-2009) 12 SMU Sci \& Tech L Rev 19 at 20.
} 
It is the authors' view that greater use of technology in legal education is inevitable, ${ }^{80}$ but like Gutenberg's printing 'revolution', the realisation of the rewards of online learning will be more of an evolution than a revolution. In particular, unless the movement to online learning is carefully managed, it simply will mimic online the standard, traditional, practices that have characterised the face-to-face teaching it replaced. ${ }^{81}$ Maharg and Muntjewerff describe this as 'profoundly paradoxical' because "technology is used by an institution to avoid change by allowing the institution to appear to embrace change through the introduction of new technology". ${ }^{82}$ Given the movement of courses online, the ability to challenge the dominant paradigm then becomes more difficult. ${ }^{83}$

Institutions are not the only catalysts of such a paradox. Legal academics may either consciously, or unwittingly, transfer online, and teach, units in the same way such units were taught face-to-face; particularly if the online learning software allows for synchronous delivery. For example, an expository approach may be adopted where content is transmitted through digital devices. Lecturers upload online course materials - for example, links to case law and journal articles, etc - and present lectures

\footnotetext{
${ }^{80}$ In this we agree with Binford who noted that "the emerging omnipresence of digital technologies in legal education is inescapable": W W Binford, 'Envisioning a Twenty-first Century Legal Education' (2013) 43 Wash U J L \& Policy 157 at 158. See also E Noam, 'Electronics and the Future of Law Schools' (2008) 17 J Contemp Legal Issues 51 at 63.

${ }^{81}$ P Maharg, A Muntjewerff, 'Through a Screen Darkly: Electronic Legal Education in Europe' Europe' (2002) 36 Law Teacher 307 at 311.

${ }^{82} \mathrm{P}$ Maharg, A Muntjewerff, 'Through a Screen Darkly: Electronic Legal Education in Europe' Europe' (2002) 36 Law Teacher 307 at 311.

${ }^{83}$ P Maharg, A Muntjewerff, 'Through a Screen Darkly: Electronic Legal Education in Europe' Europe' (2002) 36 Law Teacher 307 at 311.
} 
synchronously through the online platform. This results in little control being vested in the student. Student's simply work their way through course materials in a set sequence, much as they did in a traditional face-to-face lecture. ${ }^{84}$ Such an approach can be contrasted with interactive learning where students work together, either synchronously or asynchronously, through group learning activities to explore information and solve problems. ${ }^{85}$ For example, in the Indigenous Justice stream of CDU's clinical unit, discussed below, students working on a tort class action collaborated synchronously in a wiki to draft documents, and communicated using both the text and chat functions in Blackboard Collaborate.

Adopting a traditional approach to teaching may be the result of inadequate training in online course design, ${ }^{86}$ or simply a desire to take the least arduous path to achieve an outcome (teaching) which, in many institutions, is still not valued as highly as other academic activities; in particular research. Whatever the cause, such an outcome will not result in the 'cure' to the pitfalls of traditional teaching practices envisioned by the enthusiasts.

\footnotetext{
${ }^{84}$ Evaluation of Evidence-Based Practices in Online Learning: A Meta-analysis and Review of Online Learning Studies (US Department of Education Office of Planning, Evaluation, and Policy Development Policy and Program Studies Service, 2010) at 4-5.

${ }^{85}$ Evaluation of Evidence-Based Practices in Online Learning: A Meta-analysis and Review of Online Learning Studies (US Department of Education Office of Planning, Evaluation, and Policy Development Policy and Program Studies Service, 2010) at 4-5.

${ }^{86}$ As Flood, writing in 2015, noted, "Law faculty have not fully embraced the varieties of e-learning available to them nor have they been trained in their use": J Flood, 'Global Challenges for Legal Education: Competing for the World's Law Students' (2015) 24 Nottingham L J 79 at 86.
} 
Further, by definition undertaking a law degree fully online will not result in a student obtaining a 'campus experience'. Many law students, however, will have already had an on-campus experience in a prior undergraduate degree. This is particularly the case in jurisdictions, such as Canada and the United States, where the first degree in law is preceded by an undergraduate degree in another discipline.

In addition, for mature age students, which make up a significant percentage of those undertaking fully online law degrees, having an on-campus experience may not be as important as it is to a school leaver ${ }^{87}$ entering university for the first time. At CDU, for example, of the 855 law students enrolled in CDU's law degree program in $2015,{ }^{88}$ $71.35 \%$ were 25 years or over. Of the $28.65 \%$ of law students under 25 years, only $3.16 \%$ enrolled as school leavers. ${ }^{89}$

These numbers compare to at least one other Australian regional university offering online law degree programs. While the data is somewhat dated, Collins noted that in 2008 that only 32\% of the University of Southern Queensland students were under 25 years of age, and $70 \%$ of students enrolled in the law degree program studied in a

\footnotetext{
${ }^{87}$ 'School leaver', as that term is used at CDU, means a commencing student whose highest educational attainment before commencement of their course enrolment was a completed final year of secondary education in the academic year or two years prior.

${ }^{88}$ Of the total of 855 students, $302(41.29 \%)$ studied full-time and 502 (58.71\%) studied part-time.

${ }^{89}$ In almost all Australian law schools, students can commence their law degree program immediately after completing their secondary education. The exception is Melbourne University Law School, which offers only a JD degree taught at a graduate level.
} 
distance education mode. ${ }^{90}$ It appears that a similar trend is evident in at least one online law school in the United States, Concord Law School. Cahak notes that,

[a]lthough nearly all applicants to brick-and-mortar law schools [in the United States] are under the age of thirty, the average Concord student is forty-three years old. Furthermore, $40 \%$ of Concord's student body possess a previous graduate degree..$^{91}$

Finally, given that "the lives of our students are inextricably linked with technology", ${ }^{92}$ the 'on-campus experience' many, particularly older, commentators envision is very different from the actual experience of our students. We are reminded of a café sign one of the authors saw in Bali which read: "No, we do not have Wifi. Try talking to each other." Those undertaking an online law degree generally have other priorities, including where they live, cost, work and family commitments, and desire for flexibility in the way they study, which outweigh the need to study on-campus.

Feelings of isolation are perhaps the greatest risk of online learning. ${ }^{93}$ Computer mediated communication, be it audio, visual or written, is not the same as communicating face-to-face. It is generally acknowledged that non-verbal

\footnotetext{
${ }^{90}$ See P Collins, 'Inclusive team assessment of off-campus and on-campus first year law students using instantaneous communication technology' (2010) 44 Law Teacher 309 at 312.

${ }^{91}$ A Cahak, 'Beyond Brick-and-Mortar: How (Cautiously) Embracing Internet Law Schools Can Help Bridge the Legal Access Gap' [2012] U Ill J L Tech \& Policy 495 at 502. As has been noted above, students in the United States cannot enrol in a law degree without a prior degree in another discipline, therefore, the age of law students is generally higher than in Australia.

${ }_{92} \mathrm{~J}$ Rosenberg, 'Confronting Cliches in Online Instruction: Using a Hybrid Model to Teach Lawyering Skills' (2008-2009) 12 SMU Sci \& Tech L Rev 19 at 82.

${ }^{93}$ Not all would agree with that online education can be an isolating experience. For example see,

E Fredericksen, 'Is online education good or bad? And is this really the right question?' (The

Conversation, 4 February 2015): https://theconversation.com/is-online-education-good-or-bad-and-isthis-really-the-right-question-35949 (accessed 11 October 2016).
} 
communication, consisting of a person's appearances, movements, expressions and body language, makes up a significant percentage of our communication. ${ }^{94}$ While the use of audio and visual conferencing facilities available through online systems software can pick up some of the non-verbal cues, many are missed. It can be anticipated that the software will continue to improve, however, we are not yet at the stage where such software can duplicate the face-to-face experience. ${ }^{95}$

Further, it goes without saying that sitting alone in front of a computer is a very different experience to physically attending (or teaching) a class full of one's peers (or students). In the virtual classroom, interaction tends to be more stilted, although again advances in technology will continue to narrow the gap between online and face-toface communication. In particular, continued advancements in the integration of audio, video, whiteboard and chat facilities in online educational software will improve the students' learning experience.

Those teaching online units need to think creatively about how to minimise the feelings of isolation that will arise from learning online. This may involve a complete re-conceptualisation of what learning tasks and activities constitute an online classroom experience. In particular, an interactive, rather than an expository,

\footnotetext{
${ }^{94}$ P Peters, 'Gaining Compliance Through Non-Verbal Communication' (2007) 7 Pepp Disp Resol L J 87. Peters, relying on the studies cited in $\mathrm{fn} 1$ of her article, maintains that such non-verbal communication constitutes $55 \%$ of our communication.

${ }^{95}$ For an interesting discussion of real as compared to virtual spaces, see L Gibbons, 'Law and the Emotive Avatar' (2009) 11 Vand J Ent $\mathcal{E}$ Tech L 899. For a discussion of the use of non-verbal communication in the courtroom, see L McCrimmon, I Maxwell, 'Teaching Trial Advocacy: Inviting the Thespian into Blackstone's Tower' (1999) 33 Law Teacher 31.
} 
framework for online learning should be adopted. For example, increasing use of student collaboration and teamwork involving high levels of peer to peer communication, ${ }^{96}$ increasingly sophisticated virtual learning environments, ${ }^{97}$ and interactive simulator programs, ${ }^{98}$ should become standard components of a welldesigned online unit. ${ }^{99}$ The use of such tools and teaching methods will help to alleviate, but not eradicate, feelings of isolation.

Admittedly, such methods and tools are not the exclusive purview of online instruction. In the latter part of the twentieth century, such methods and tools have been used increasingly by Australian legal educators teaching on-campus students. ${ }^{100}$ This trend has continued, however, as Kift noted in 2006, "the pace of change from the traditional model ... has been glacially slow" ${ }^{101}$ This observation continues to resonate a decade later.

There is a cost in human and financial resources in establishing and maintaining online learning, however, to some extent this cost is inevitable in the Digital Age. Even

\footnotetext{
${ }^{96} \mathrm{~J}$ Flood, 'Global Challenges for Legal Education: Competing for the World's Law Students' (2015) 24 Nottingham L J 79 at 87 . For a discussion of the use of teamwork in an online law unit, see P Collins, 'Inclusive team assessment of off-campus and on-campus first year law students using instantaneous communication technology' (2010) 44 Law Teacher 309.

${ }^{97}$ For example, see P McKellar, P Maharg, 'Virtual Learning Environments: The Alternative to the Box Under the Bed' (2005) 39 Law Teacher 43.

${ }^{98}$ E Noam, 'Electronics and the Future of Law Schools' (2008) 17 J Contemp Legal Issues 51 at 59-60.

${ }^{99}$ See also C Dunham, S Friedland, 'Portable Learning for the $21^{\text {st }}$ Century Law School: Designing a New Pedagogy for the Modern Global Context' (2009) 26 J Marshall J Computer \& Info L 371.

100 The latter part of the twentieth century in Australia saw the advent of ALTA Law Teaching Workshop (in 1988), and the publication of influential texts on learning in higher education; the two most influential being: M Le Brun, R Johnstone, The Quiet Revolution (The Law Book Company, 1994), and P Ramsden, Learning to Teach in Higher Education (Routledge, 1992).

${ }^{101}$ S Kift, 'My Law School - Then and Now' (2006) 9 Newcastle L Rev 1 at 10.
} 
law schools which do not offer online degrees have to invest a significant amount in the infrastructure of online learning - computers, fast internet connection, access to online research databases, and, of course, the technical expertise required to maintain such equipment. Further, increasingly law schools are implementing online learning software to facilitate staff/student interaction outside of on-campus lectures and tutorials, provide an online space for students to interact, and to facilitate the writing and submission of written work.

On the 'rewards' side, however, it must be noted that there is a cost-saving to students who undertake their studies online. In Australia, funding rates for Australian Government supported places do not differentiate between degrees taught online and degrees taught on campus. This means that the cost of the degree program generally will be the same regardless of the mode in which the degree is taught. As has been noted above, however, for students living in remote, rural and regional centres there are inherent cost savings in not having to move to a larger metropolitan centre to attend university; which could include, for example, the cost of moving, renting accommodation and transportation. Further, for students with mobility issues or with child care responsibilities, it is often more cost effective to stay at home while completing their degree, thereby avoiding transportation and child-care expenses. Finally, for those in full-time employment, undertaking a degree online provides the flexibility to complete the degree program without taking time off work to attend oncampus classes. 
For CDU, like many regional law schools in Australia, investing in the establishment and maintenance of online learning infrastructure is critical to the law school's survival. The closest major centre to Darwin, where CDU law school is located, is Adelaide, which is over 3,000 km away. In fact, Darwin is closer to Jakarta, Indonesia $(2,700 \mathrm{~km})$, than to any Australian capital city. As at June 2015, the Northern Territory had population of $244,600,{ }^{102}$ of which over one-half $(140,400)$ live in the greater Darwin area. ${ }^{103}$ The catchment area simply is too small to support an on-campus only law school, as evidenced by the fact that only $19 \%$ of CDU law students study oncampus or in mixed mode (both on-campus and online), and $81.05 \%$ study fully online.

The size of the potential student catchment area, together with the large number of law schools per capita ${ }^{104}$ and the fact that Australian students tend not to travel interstate to attend university, means that law schools in regional centres have had to embrace online learning. For many, including CDU, it was more a question of survival than choice.

The provision of an online law degree program vastly expanded CDU's ability to attract students. As at 2015, the home location of CDU law students, as defined by the

\footnotetext{
102 ABS, Australian Demographic Statistics, Jun 2015: www.abs.gov.au/ausstats/abs@.nsf/mf/3101.0 (accessed 27 September 2016).

${ }^{103}$ www.abs.gov.au/ausstats/abs@.nsf/mf/3218.0 (accessed 27 September 2016).

104 As has been noted above, Australia has 36 law schools servicing a domestic population of 24 million people. By comparison, Canada has just under 36 million people and only 18 law schools teaching common law. For population figures see: $\underline{\text { www.countrymeters.info (accessed } 27 \text { September }}$ 2016).
} 
Australian Bureau of Statistics' Australian Standard Geographical Classification, ${ }^{105}$ was as follows:

Table 2: CDU law student enrolments by home location remoteness (2015)

\begin{tabular}{|l|r|}
\hline Home location & Enrolment percentage \\
\hline Major Cities of Australia & $76.14 \%$ \\
\hline Inner Regional Australia & $9.71 \%$ \\
\hline Outer Regional Australia & $7.72 \%$ \\
\hline Remote Australia & $3.39 \%$ \\
\hline Very Remote Australia & $0.82 \%$ \\
\hline International & $2.22 \%$ \\
\hline Total & $\mathbf{1 0 0 . 0 0 \%}$ \\
\hline
\end{tabular}

Leaving a law school's economic survival to one side, the provision of an online law degree also allowed 22\%, or approximately 190 students, from regional Australia to undertake a law degree at CDU. Considering that CDU is but one Australian university offering a law degree fully online, the opportunity online education provides to those living in regional centres to undertake law studies is self-evident.

The above discussion illustrates that it is fallacious to characterise the economic cost of establishing and maintaining online learning as a risk. The well-known American

${ }^{105}$ Available at www.abs.gov.au (accessed 27 September 2016). 
economist Professor Eli Noam correctly noted in his 2008 article, 'Electronics and the Future of Law Schools', that:

The question is not whether universities and law schools are important to society, to knowledge, or to their members - they surely are - but rather whether the economic foundation of the present system can be maintained and sustained when electronic communication provides alternatives. These are the drivers of change. Research and teaching as activities will not be questioned - they will be more important than ever but rather their present main instructional setting. We have come to equate legal education with traditional law schools. Not much longer. ${ }^{106}$

For a law school perched at the top of Australia, the movement to an online law degree program was critical to the law school's continued existence. If the Northern Territory wanted its only university to have a law school, an online degree program had to be included in its suite of offerings.

\section{Online clinical legal education at CDU}

As has been noted above, CDU has developed a legal clinic elective for online and oncampus students. In this section, we discuss the development of the unit, the assessment regime, the unit learning outcomes and the experiences of students undertaking the program.

Approximately $75 \%$ of the students enrolled in the clinical unit have been, and in the future are expected to be, online students. The unit began as a placement program

${ }^{106}$ E Noam, 'Electronics and the Future of Law Schools' (2008) 17 J Contemp Legal Issues 51 at 63. 
within an existing environmental law unit in 2014, and was expanded in 2015 to include placement opportunities in refugee law and Indigenous justice, and with Reprieve Australia. In 2016, the pilot program became a fully accredited unit available to on-campus and online students entitled, somewhat unimaginatively, Legal Clinic. The unit aims to:

- improve students' practical legal skills such as client interviewing, research, communication and legal drafting;

- $\quad$ instil in students a sense of professional responsibility and social justice; - $\quad$ promote student participation in community and professional engagement;

- $\quad$ meet legal need amongst vulnerable and disadvantaged members of society in the Northern Territory and internationally; and

- $\quad$ foster students' understanding of the global nature of legal practice.

Enrolment in the unit is limited based on the number of placement sites and the capacity of the particular site to accommodate students. Students apply for admission to the unit and are required to submit an expression of interest outlining the aspects of legal practice in which they are interested, and why they wish to undertake Legal Clinic. If accepted into the unit, students are allocated to an organisation that matches as closely as possible their interest in a particular area of practice. Further, students are required to sign a confidentiality agreement in a form approved both by CDU and the placement site. The ethical issues surrounding client confidentiality also are explored in the first of the weekly legal skills workshops, discussed below. 
The host organisations include local Darwin law firms undertaking pro bono work, local legal non-governmental organisations ('NGOs'), community legal centres interstate and international organisations involved in pro bono legal assistance. Both online and internal students are accommodated at the placement site and, as is discussed below, online students have been accommodated in all but one placement site.

The streams, and the organisations that took part in the program in 2015, are outlined below, together with a description of how online students participated in the program. These streams constitute the Legal Clinic unit being offered in the first semester of 2016.

\section{Environmental law stream}

Students have been placed with one of two organisations:

1. the Legal Response Initiative, which is an international pro bono organisation that provides advice to developing countries on climate change obligations under the United Nations Framework on Climate Change and working groups associated with the Climate Change Convention; and

2. the Environment Defenders Office of the Northern Territory, which is a Northern Territory based community legal centre specialising in public interest environmental matters and access to justice.

Online students placed in both organisations communicated with their supervising lawyer via skype, email and telephone. Documents were shared via email in accordance with the site's policies regarding client confidentiality and secured 
document transfer, and online resources were used for research purposes. Within the Environment Defenders Office, students had the opportunity to sit in on a client interview by phone (with the client's permission).

\section{Refugee Law stream}

Students were placed with a local Darwin law firm within the firm's pro bono refugee law program. The placement site accommodated one online student who was partnered with a local student. The students undertook research on a current case being handled by the firm, and observed the supervising lawyer in court. The online student attended court hearings online via the Federal Court's video-link system. The local, but not the online, student also observed client interviews.

\section{Internship with Reprieve Australia}

This placement site accommodated one online student who took part in researching and drafting a submission to the Joint Standing Committee on Foreign Affairs and Trade on the topic of Australia's advocacy internationally for abolition of the death penalty. The student was supervised by a member of Reprieve Australia, and a CDU academic with experience in death penalty cases. The student's work reflected as closely as possible international legal practice involving the drafting of policy based reports and submissions.

\section{Indigenous Justice stream}

The Indigenous Justice stream had three components: 
1. a placement with a Darwin law firm acting on behalf of Indigenous claimants in a tort class action relating to the sexual abuse of children while resident at a children's home in Darwin from 1947-1981. Darwin based and online students carried out legal research into both the substantive law relating to the abuse, and the procedural issues related to the running of a class action. They also attended client interviews, took witness statements, drafted documents and accessed physical resources close to their home location such as government archival records. Online students participated in interviews and meetings using Blackboard Collaborate and telephone. The supervising lawyers also met face to face with online students if the lawyers had occasion to travel to where the students were living.

2. an Indigenous Justice and Exoneration project which focused on freeing innocent persons who had been wrongly convicted. Students, working under the supervision of a lawyer based in the state of Tasmania, researched relevant legal issues pertaining to an ongoing appeal for a conviction of murder and investigated whether there was any admissible new evidence. The students in this component also researched and produced for the United Kingdom based Advocates Gateway ${ }^{107}$ an advocacy toolkit pertaining to the effective participation of Indigenous people in the justice system. Students also

${ }^{107}$ The Advocates Gateway is a United Kingdom based organisation set up to help address communication needs in the justice system. See www.theadvocatesgateway.org (accessed 16 February 2016). 
produced policy documents and reports requested by the Advocates Gateway Indigenous steering group. The placement simulated as far as is possible an international law firm as online students communicated with supervisors and each other in person, using Blackboard Collaborate, and by email. All research was undertaken using online or digital resources.

3. a placement at the North Australian Aboriginal Justice Agency (NAAJA), ${ }^{108}$ in the Local Court bail section, where students were actively involved in assisting their supervising lawyer in seeking bail for disadvantaged Indigenous clients. Students interviewed clients and made contact with family members on behalf of clients. Given the nature of the work done at the placement site, NAAJA requested that only Darwin based students be placed with the organisation.

As with traditional externship placements, students were supervised by a lawyer within the organisations as well as by a CDU academic who met with the students, either face-to-face or online, regularly throughout the placement. The students' placement experience also was supplemented by weekly legal skills workshops. Such workshops were presented face-to-face for on-campus students and online using Blackboard Collaborate for external students. The workshops covered practical lawyering skills such as client interviewing, mediation, working with interpreters and

${ }^{108}$ NAAJA is an aboriginal legal service which addressed the legal need of disadvantaged Indigenous Australians living in the northern part of the Northern Territory. 
legal research and writing skills. ${ }^{109}$ Professional responsibility issues such as legal professional privilege and maintaining client confidentiality were addressed, and the workshops also provided an opportunity for students to share with each other their experiences at various placement sites.

\section{Assessment}

The assessment consisted of a reflective journal, worth $70 \%$ of the final mark, and an essay, worth $30 \%$. The reflective journal was used to enable students to analyse critically how knowledge and skills acquired through the study of law related to the legal practice setting in which they were placed. In particular, students had the opportunity to reflect on how their legal knowledge and skills could be used to achieve social justice outcomes. The reflective journal also allowed students to reflect on their personal motivations for studying law, and their goals and career aspirations. Finally, it provided students with a record of their personal and professional growth during the course of the placement, and, hopefully, equipped them with the skills to be a self-reflective professional.

Once the weekly entry in the students' reflective journals were completed, they were submitted, either by email or through the submission function in Blackboard Collaborate, to the academic responsible for the stream. Students received weekly

\footnotetext{
${ }^{109}$ If a particular need was not covered in the workshop program, then additional skills workshops were scheduled. For example, the need for further skills training was identified often in the students' reflective journals.
} 
feedback on their journal entries. Further, the students' well-being, skill development, placement experiences, and communications skills were monitored through their reflective journal entries. ${ }^{110}$

That timely and relevant feedback enhances student learning and their learning experience is undisputed, ${ }^{111}$ however, a reflective journal also assists students to understand the subject matter, ${ }^{112}$ and develop their legal identity. ${ }^{113}$ Students had the opportunity to amend their journal entries after receiving feedback from the CDU academic responsible for the unit. This was critical as the purpose of the reflective journal was both for formative and summative assessment. ${ }^{114}$ The revised journal was graded at the end of the semester with input from the supervisor at the placement site. In addition to the reflective journal, the individual student's well-being and experiences at the placement site was monitored in regular meetings between the student and the CDU supervising academic. These meetings took place either by phone, in person (if possible), by Skype or through Blackboard Collaborate.

\footnotetext{
${ }^{110}$ It is widely agreed that a reflective practice enhances learning, promotes wellbeing and psychological health and is useful for professional development for work and life. For example see J McNamara, T Cockburn, C Campbell, Good Practice Guide (Bachelor of Laws): Reflective Practice (Australian Learning and Teaching Council, 2011) at 11.

${ }^{111}$ Stuckey, R et al, Best Practices for Legal Education: A vision and a Road Map, (Clinical Legal Education Association, 2007) at 174-177.

112 J McNamara, T Cockburn, C Campbell, Good Practice Guide (Bachelor of Laws): Reflective Practice (Australian Learning and Teaching Council, 2011) at 11

${ }^{113}$ L Barron, 'Learning how to Learn: Carnegie's Third Apprenticeship' (2011) 18 Clinical Law Review 101 at 101-103.

114 For a discussion of formative and summative assessment see M Le Brun, R Johnstone, The Quiet Revolution: Improving Student Learning in Law (Law Book Co, 1994) at 181-182; J McNamara, T Cockburn, C Campbell, Good Practice Guide (Bachelor of Laws): Reflective Practice (Australian Learning and Teaching Council, 2011).
} 
The assessment rubric and 'prompt' questions for completing the reflective journal, adapted from Burton and McNamara's article on assessing the skills of reflection, ${ }^{115}$ were provided to students at the beginning of the semester. Students also were given a guide which covered the purpose of reflective journals and instructions on how to complete the weekly entries.

The second component of the assessment tasks used in the unit was an essay question. The essay questions were set in consultation with the students' placement site and related to a piece of work that the student was expected to undertake during the placement. The essay question was designed to assist students to gain a better understanding of the concept of social justice, in addition to being of benefit to the placement site. ${ }^{116}$

\section{Feedback from the pilot unit}

At the conclusion of each semester, informal verbal feedback and formal written feedback was sought from the students, site supervisors, and CDU academics who participated in the program. Of particular note was the difference in the students' experience of the program.

\footnotetext{
${ }^{115} \mathrm{~K}$ Burton, J McNamara, 'Assessing reflection skills in law using criterion-referenced assessment'. (2009) 19 Legal Ed Rev (2009) 171 at 184.

116 For example, the question set in consultation with the Legal Response Initiative was: "Inequities in wealth and resources can lead to inequitable outcomes, particularly on the world negotiating stage. Discuss a strategy developed and used under the United Nations Climate Change Framework that aims to address the inequities between negotiating States and evaluate whether it addresses an inequity meaningfully." This related to the students' specific research for the placement site, which concerned developing nations' obligations and abilities to access funding under the United Nations Climate Change Framework.
} 
While it was anticipated that experiences would differ depending on whether the student was a local or online, such a difference was not reflected in the feedback. Rather, student satisfaction was influenced by such factors as: the ability to work collaboratively with other students, whether online or local; the allocation and explanation of set tasks by site supervisors; and the receipt of timely feedback from site supervisors and academic advisors. In this regard, the feedback received was no different than what might be expected from an externship unit that did not accommodate online students. ${ }^{117}$

Local and online students who were allocated a placement site as part of a student group, and given set roles within that group, reported the highest levels of satisfaction with the program. Conversely, those students who were placed individually with an organisation, either locally or in an online externship, reported feeling isolated and unsure of their supervisors' expectations.

Strategies used to address feelings of isolation included increased CDU academic monitoring of the students, and facilitating student discussion of their experiences at the placement site as part of the weekly workshops. As a result of these strategies, students reported decreased feelings of isolation, and increased feelings of being a

\footnotetext{
${ }^{117}$ L Ryan Cole, L Wortham, “Learning from Supervision' (in L Wortham, A Scherr, N Maurer, S Brooks eds, Learning from Practice: A Text for Experiential Legal Education (West Academic Publishing, 2016)) at 33-34; S McClellan, 'Externships for Millennial Generation Law Students: Bridging the Generation Gap' (2009) 15 Clinical Law Rev 255 at 272-274, 276-278.
} 
part of a common endeavour. Further, those students who were not placed at a site as part of a group also made efforts to continue contact with other students placed alone.

Finally, the students reported high levels of satisfaction with the primarily online communication methods, subject to timely feedback from supervisors. Students living in rural and remote areas were particularly satisfied with online communication and online placements.

Supervisors generally were happy with the provision of online supervision, although the CDU staff responsible for the unit had to work closely with site supervisors to explain how the online platforms worked. Some of the other initial issues that needed to be addressed included ensuring confidentiality, software compatibility, internet connectivity and scepticism arising from the supervision of students that the supervisor had never met in person. Once the supervisor's unfamiliarity with the technology was addressed, however, and the supervisor met the online student using the video-conferencing facilities, such initial reluctance was overcome. ${ }^{118}$

To take but one example, in the Indigenous Justice stream the supervising lawyer in the tort class action case took part in the first online Blackboard Collaborate workshop session with students. Such participation demonstrated to the lawyer the capacity for synchronous engagement with students through the use of Collaborate's audio, video

\footnotetext{
${ }^{118}$ It should be noted that some organisations, such as the Legal Response Initiative based in the United Kingdom, did not have any concerns with supervising students remotely as such supervision was routinely done at that organisation.
} 
and chat facilities. Subsequently, the lawyer was able to interact both synchronously and asynchronously with both local and online students using phone, email and Collaborate. He also was able to monitor the work done by students, and the studentto-student interaction, on the Smartsheet data entry system ${ }^{119}$ used to organise the voluminous documents pertaining to the case.

\section{Lessons learned and possible refinements}

While student feedback indicated that students generally were satisfied with their experience at the placement site even if they are unable to experience immediate interaction with clients, increasing opportunities for such real client interaction was one refinement that has been identified as a worthwhile goal by CDU staff involved in the various streams. Consequently, ways to expand Legal Clinic to increase external students' opportunities to interact with clients are being explored, including:

- developing relationships with host organisations in other cities (especially those with significant external enrolments such as Adelaide and Melbourne);

- offering external students the opportunity to travel to Darwin (hopefully with a travel subsidy) to undertake intensive placement with a Darwin host organisation; ${ }^{120}$ and

\footnotetext{
${ }^{119}$ For a discussion of the Smartsheet data entry system, see: www.smartsheet.com (accessed 11 October 2016).

${ }^{120}$ Research suggests that a blend of online and face-to-face instruction provides the most effective learning environment: Evaluation of Evidence-Based Practices in Online Learning: A Meta-Analysis and Review of Online Learning Studies (US Department of Education Office of Planning, Evaluation, and Policy Development Policy and Program Studies Service, September 2010) at xviii.
} 
- offering online (and internal) students the opportunity to work more closely with the courts. In this regard, judges of the Northern Territory Local Court in Darwin have expressed interest in hosting both online and local students as quasi-associates on an intensive placement. This would give external students further opportunities for real-time interaction with both civil litigants and criminal defendants before the Court.

Student workload is another aspect of the Legal Clinic unit currently under review. Generally, over the 12 week semester, students are expected to devote 6-8 hours per week to placement site work, attend a two hour workshop each week, and complete both a 2000 word research essay and a 3000 word reflective journal. Whatever the objective reality, there is a perception among students that the workload and time demands of the Legal Clinic are excessive compared to other elective units. While clinical units generally require a substantial commitment on the part of students, there is scope to address workload issues while still achieving the unit's educational objectives.

In particular, changes to the unit delivery structure under consideration include replacing the weekly workshops with an intensive weekend seminar at the beginning of each teaching semester. The intensive seminar would include the key content currently covered in the weekly workshops, together with simulated client interviews and other role plays to prepare students better for real client interaction. In addition to the intensive seminar, students would attend a fortnightly online meeting with the 
stream academic supervisor. In the meetings, experiences at the placement site could be discussed, and any issues with the placement identified.

\section{CONCLUSION}

With advances in digital technology, the next major advance in the evolution of clinical legal education is upon us. In 2000, when envisioning the impact of technology on clinical legal education, Martin Barry, Dubin and Joy noted:

Improvements and cost reductions in distance learning and video conferencing technologies will provide greater opportunities for clinical work across local, state and national borders and permit more mult-school, multi-venue collaborations. This technology will be particularly useful in expanding externship offerings and increasingly their sophistication. ${ }^{121}$

What was speculation in 2000 has now been realised, at least at CDU. Online students undertaking CDU's Legal Clinic in 2016 have the opportunity to work with Darwinbased, national and international organisations in a wide variety of public interest placements. Further, CDU clinicians, through their own networks and global networks such as GAJE, can work with like-minded colleagues in Asia and elsewhere to improve clinical offerings and maximise the rewards digital technologies provide.

For clinicians dedicated to instilling in our students the skills, both practical and ethical, that they will need to practice law, the advent of digital technologies has

\footnotetext{
${ }^{121}$ M Martin Barry, J Dubin, P Joy, 'Clinical Education for this Millennium: The Third Wave' (2001) 7 Clinical L Rev 1 at 53-54.
} 
indeed provided us with a Gutenberg moment. Through advances in communications technology, a placement site now can be located anywhere in the world. Through advances in video technology, a student now can conduct an interview with a client located in another city, state or country. In the future it can be envisioned that, subject to local student practice rules, the provision of adequate supervision by site supervisors and the technical capability of individual courts, a student in a remote region of Australia could appear in a court in any Australian city.

In Australia, it can be anticipated that law schools situated in regional areas will pioneer the use of technology to change the way our students learn, and the way in which we as legal educators teach. The challenge for any law school incorporating technology into its clinical offerings is to ensure that the rewards are maximised and the inevitable risks minimised. In particular, great care must be taken to ensure that a student's feelings of isolation, which is an inherent risk of online learning, are minimised.

The greater use of technology in legal education is inevitable, and it makes sense to harness the benefits such technology provides to expand the scope and content of, and student participation in, a law school's clinical offerings. While this article has focused on developments in Australia, clinical legal education is a global movement and the inherent benefits of online clinical legal education are not defined by national borders. While each country faces unique challenges in terms of accreditation of online degrees, access to a fast and reliable network, and access to the resources necessary to 
implement online degree programs, it is our hope that CDU's experience will assist others considering the implementation of online clinical opportunities for law students. How such a change is effected will be both a significant challenge, and an exciting opportunity, facing clinical legal educators in the twenty-first century. 